\title{
Richtlijnontwikkeling over aanvalsdetectie
}

De richtlijn Epilepsie wordt jaarlijks geactualiseerd. De laatste jaren is er een enorme ontwikkeling op het gebied van aanvalsdetectie bij patiënten met epilepsie. Hierover is echter nog vrijwel niets opgenomen in de richtlijn. In $2019 \mathrm{zal}$ een nieuwe module over aanvalsdetectie in de richtlijn Epilepsie verschijnen. In deze bijdrage wordt besproken hoe deze nieuwe module tot stand komt.

\section{Aanvalsdetectie}

De laatste jaren is aanvalsdetectie in de woonsituatie van patiënten met epilepsie sterk in ontwikkeling. Het is belangrijk om te weten hoe vaak iemand een aanval heeft en wat voor soort aanval dat is. In de praktijk gebeurt dit door patiënten en andere betrokkenen de aanvallen in een dagboek te laten bijhouden. Apparaten die betrouwbaar aanvallen kunnen registreren zullen naar verwachting nauwkeuriger zijn. Tevens kan aanvalsdetectie worden gebruikt voor het alarmeren bij het optreden van een epileptische aanval. Het is aannemelijk dat hiermee de morbiditeit en mortaliteit bij patiënten met epilepsie wordt verlaagd. Dit kan bijdragen aan een betere kwaliteit van leven.

Er zijn veel verschillende ambulante methodes van aanvalsdetectie. Er zijn systemen die gebaseerd zijn op detectie van beweging en/of op verschijnselen veroorzaakt door een verandering in het autonoom zenuwstelsel die optreden bij aanvallen (bijvoorbeeld hartslagveranderingen, zweten). Beschikbare systemen zijn bijvoorbeeld accelerometers die bewegingen en lichaamshouding registreren, matrassensoren, elektromyografie om de spiercontractie te meten en ECG om de hartfrequentie en variabiliteit hierin te meten. Ook kan gekeken worden naar de elektrodermale activiteit, saturatie of respiratie.

\section{Richtlijn Epilepsie}

De richtlijn Epilepsie biedt ondersteuning in de dagelijkse praktijkvoering bij de diagnostiek en behandeling van epilepsie. De gegeven aanbevelingen berusten op wetenschappelijk onderzoek aangevuld met expertise van zorgverleners of ervaring van zorggebruikers. Bij de vergadering van de richtlijnwerkgroep bleek er behoefte aan het toevoegen van een module over aanvalsdetectie. Voor het ontwikkelen van een nieuwe module worden vele stappen doorlopen, van het analyseren van knelpunten en het formuleren van uitgangsvragen tot het doen van een aanbeveling.

\section{Ontwilkkeling van een nieuwe module}

Periodiek wordt geïnventariseerd of er nieuwe onderwerpen in de richtlijn aandacht behoeven. Daarbij wordt een uitgangsvraag geformuleerd, dat wil zeggen een klinisch relevante vraag waarop tijdens de richtlijnontwikkeling een antwoord wordt geformuleerd. De uitgangsvraag voor de module aanvalsdetectie werd als volgt geformuleerd: 'Wat is de betrouwbaarheid en bruikbaarheid in de thuisof woonsituatie van aanvalsdetectie gebaseerd op beweging, hartslagfrequentie(variabiliteit), elektromyografie, geluid en elektrodermale activiteit voor het detecteren en alarmeren van epileptische aanvallen bij patiënten met epilepsie?' De eerste stappen voor het beantwoorden van deze vraag zijn inmiddels genomen.

Om de uitgangsvraag te kunnen beantwoorden werd deze eerst omgezet naar een PICO-gestructureerde zoekvraag. Deze vraag bevat vier componenten, namelijk een beschrijving van Patient, Intervention, Comparison en Outcome. Hier werd een systematische literatuuranalyse naar verricht, waarvoor werd gezocht in de databases Medline (PubMed) en The Cochrane Library met relevante zoektermen waaronder epilepsy, detection, prediction, monitoring, alarm, alarming, automatic en ambulatory gecombineerd met accelerometry, actigraphy, electrodermal activity, heart rate, heart rhythm en sound. Er werd gezocht in Engelstalige en Nederlandstalige publicaties, er waren geen beperkingen met betrekking tot het jaar van publiceren. De literatuurzoekactie leverde 574 publicaties op, bestaande uit systematische reviews, randomised controlled trials, case control- en cohort studies en I50 review-artikelen. Op basis van titel en abstract vond een voorselectie plaats van studies die aansloten bij de zoekvraag, waarvan de volledige tekst werd geraadpleegd. Op basis hiervan werden dertien studies definitief geselecteerd.

Om een antwoord te krijgen op de zoekvraag worden momenteel de data uit deze studies geëxtraheerd door middel van het opstellen van een evidence table, waarbij wij 
gebruik maken van de GRADE methodiek, ontwikkeld door de GRADE working group van The Cochrane Collaboration (Schünemann et al., 2013). Tevens wordt het risico op bias beoordeeld. De evidence tables en risk of bias assessments zijn soms lastig in te vullen als het gaat om aanvalsdetectie. Om meer inzicht te krijgen in het niveau van bewijs maken wij daarnaast gebruik van de standaard die Beniczky en Ryvlin voorstellen voor het testen en klinisch valideren van methoden voor aanvalsdetectie (Beniczky \& Ryvlin, 2018). Deze standaard kan helpen bij het opzetten van een nieuwe studie, maar ook van aanvullende waarde zijn bij het beoordelen van een studie door inzicht te geven in het niveau van bewijs. Afhankelijk van vier belangrijke kenmerken van de studieopzet; te weten de personen die deelnemen, de manier van registreren, de manier van analyse en alarmeren en de referentiestandaard, kunnen studies geclassificeerd worden in vijf verschillende niveaus (0-4), waarbij een 'niveau 4' studie de grootste bewijskracht heeft.

Om patiënten en professionals op de hoogte te houden van de snel veranderende omstandigheden houden in Nederland de epilepsiecentra (SEIN en ACE Kempenhaeghe) en het UMC Utrecht een website bij over aanvalsdetectie: www.aanvalsdetectie.nl. Op deze site staan de laatste ontwikkelingen. Er worden hier vooralsnog geen adviezen gegeven, die zullen vooral uit de richtlijnen dienen te komen, maar het betreft een overzicht van beschikbare middelen.

Alle geëxtraheerde data worden vervolgens geanalyseerd en per uitkomstmaat gegradeerd. Er bestaan verschillende systemen om het verkregen bewijs te graderen, waarbij wij de GRADE-methodiek hebben gebruikt. Op basis van de literatuur wordt een conclusie geformuleerd die een bepaalde bewijskracht heeft. Als laatste wordt een aanbeveling geformuleerd. In de aanbeveling worden naast de gegradeerde literatuurconclusies ook andere aspecten meegenomen, zoals de expert opinion van de werkgroep en ook de kosten.

Als al deze stappen doorlopen zijn, zal de nieuwe module over aanvalsdetectie in de richtlijn Epilepsie worden opgenomen, naar verwachting eind 2019. Hiermee wordt het voor de gebruikers van de richtlijn duidelijker wat de betrouwbaarheid en bruikbaarheid van verschillende methoden van aanvalsdetectie zijn bij patiënten met epilepsie. In de spreekkamer kan vervolgens samen met de patiënt en diens familie worden besproken of en hoe dit kan worden ingezet.

\section{Referenties}

Arends J, Thijs R, Gutter T et al. (in press) Multimodal nocturnal seizure detection in a residential care setting: a long-term prospective trial. Neurology, in press.

Arends JB, van Dorp J, van Hoek D et al. (20I6) Diagnostic accuracy of audio-based seizure detection in people with epilepsy with severe epilepsy and an intellectual disability. Epilepsy Behav. 62:180-185.

Beniczky S, Ryvlin P (2018). Standards for testing and clinical validation of seizure detection devices. Epilepsia 59 (S 1):9-13.

Geertsema EE, Thijs RD, Gutter T et al. (2018) Automated video-based detection of nocturnal convulsive seizures in a residential care setting. Epilepsia Jun;59 Suppl 1:53-60. Harden C, Tomson T, Gloss D et al. (2017) Practice guideline summary: sudden unexpected death in epilepsy incidence rates and risk factors: report of the Guideline Development, Dissemination, and Implementation Subcommittee of the American Academy of Neurology and the American Epilepsy Society. Neurology 88:16741680.

Kalitzin S et al. (2012) Automatic segmentation of episodes containing epileptic clonic seizures in video sequences. IEEE transactions on bio-medical engineering 59(12):33793385 .

Leijten FSS, Dutch TeleEpilepsy Consortium (2018)

Multimodal seizure detection: a review. Epilepsia. Jun;59

Suppl 1:42-47. doi: 10.1111/epi.14047

Schünemann H, Brozek J, Guyatt G et al. (2013) GRADE handbook for grading quality of evidence and strength of recommendations. Bijgewerkt in oktober 2013. The GRADE Working Group. Beschikbaar op www.guidelinedevelopment.org/handbook.

Van Andel J, Leijten FSS, van Delden H, van Thiel, G (2015) What makes a good home-based nocturnal seizure detector? A value sensitive design. PLoS One 10(4): 00121446.

Van der Lende M, Cox FME, Visser GH et al. (2016) Value of video monitoring for nocturnal seizure detection in a residential setting. Epilepsia 57(11):1748-1753.

\section{Hebt u de website van het Epilepsiefonds al bekeken? www.epilepsie.nl}

